\title{
Mediation in the Conflict of Legislation Resolution based on the Regulation of the Minister of Law and Human Rights Number 2 of 2019
}

\author{
Syafrizal $^{1}$, Muhammad Kamil Akbar², Rahmad Ramadhan Hasibuan ${ }^{3}$ \\ 1 Faculty of Law, Universitas Muhammadiyah Tanggerang, Indonesia \\ tflaw28@yahoo.com \\ 2 Postgraduate Study, Faculty of Law, Universitas Indonesia, Indonesia \\ kamil.akbar79@gmail.com \\ 3 Postgraduate Study, Faculty of Law, Universitas Indonesia, Indonesia \\ rahmadramadhanhsb@gmail.com
}

\begin{abstract}
Introduction to The Problem: The authority possessed by the Ministry of Law and Human Rights after the enactment of Permenkumham No. 2 of 2019 this then raises problems both juridical and theoretical. Because it was explored further, no formula was found that regulates the authority of the Ministry of Law and Human Rights (in this case the Directorate General of Legislation) to harmonize legislation through mediation, both in Law No. 39 of 2008 concerning the State Ministry and Presidential Regulation No. 44 of 2015 concerning the Ministry of Law and Human Rights. In addition, the mediation mechanism used in resolving the harmonization of laws and regulations is a mistake, because it is not appropriate if the mediation mechanism is applied in the harmonization of laws and regulations that are public (public).

Purpose/Objective Study: This paper objects are about the authority of the Minister of Law and Human Rights in the formation of Permenkumham No. 2 of 2019 and whether the Ministry of Law and Human Rights has the authority to mediate the disharmony of laws and regulations; then the next discussion about the mechanism and legal impact arising from the mediation.

Design/Methodology/Approach: This paper used qualitative research method with juridical-normative as an analysis approach.

Findings: the statutory regulations which are used as a basis to remember in Permenkumham No. 2 of 2019 no explicit delegation was found which ordered the formation of Permenkumham No. 2 of 2019, including the formulation which regulates the authority of the Directorate General of Legislation in completing the disharmony of legislation through mediation. Then in the case of mediation mechanism is a mechanism that is usually applied in cases that are private, where the parties act for and on their own behalf. so it becomes strange if mediation is used in resolving conflicting norms of laws and regulations which norms generally regulate, moreover the results of the mediation do not have binding legal force and do not provide legal impact on the validity of the norms of the agreed laws and regulations.
\end{abstract}

Paper Type: Research Article 
P-ISSN: $1412-6834$

E-ISSN: 2550-0090

Keywords: Conflict of Norms; Conflict of Legislation; Resolution

\section{Introduction}

After the enactment of the Minister of Law and Human Rights Regulation No. 2 of 2019 concerning Disharmony Settlement of Laws and Regulations through Mediation (i.e., Permenkumham No. 2 of 2019), the Indonesian Ministry of Law and Human Rights (i.e., Kemenkumham) through the Director-General of Legislation has the authority to resolve conflicts of laws and norms through mediation channels. Based on the Presidential Regulation No. 44 of 2015 and Minister of Law and Human Rights Regulation No. 29 of 2015, the resolution of clashing norms of laws and regulations through mediation channels is not the duty and function of the Ministry of Law and Human Rights or the Director General of Legislation. It draws an assumption that the authority given by Permenkumham No. 2 of 2019 to the Ministry of Law and Human Rights exceeds the authority it has.

In the Indonesian legal aspect (Law on the Establishment of Laws and Regulations No. 12 of 2011), ministerial regulations are recognized and have binding legal force if ordered by higher legislation or formed based on authority. Based on this provision, ministerial regulations must be formed based on orders from higher legislation or can also be formed based on authority. The later means the implementation of specific government affairs under statutory provisions.

In the context of the provision of 'ordered by higher legislation', the formation of Permenkumham No. 2 of 2019 has no provision in question as the legal basis (Aditya \& Winata, 2018). In another hand, in regards with the provision of 'formed based on authority,' the resolution of conflicting legal norms through mediation is not the duty as well as the function of the Ministry of Law and Human Rights (article 2-3 of President Regulation No. 44 of 2015). The 'authority' then leads to the confusion of the existence of regulation No. 2 of 2019. It is because the Law No. 12 of 2011 has explained in detail the technical formation of delegation regulations that require explicit orders from higher laws and regulations.

Article 5 of Permenkumham No. 2 of 2019 states that:

"Legislation as referred to in Article 2 that is clashing vertically and horizontally which leads to the disharmony of legal norms, conflicts of authority between ministries/institutions, also causes the unjust of public and business actors, and blocks the investment, business, national, and regional economic activities may be submitted for applications for resolution of disharmony regulations through the mediation."

This arrangement shows that there is a new mechanism of resolving the conflicting legal norms and regulations, which called a mediation mechanism.

In practice, there are legal norm control mechanisms prevalent in Indonesia; first is a legal assessment conducted by the legislative body (legislative review); second, examining the law through the executive agency (executive review), and lastly an 


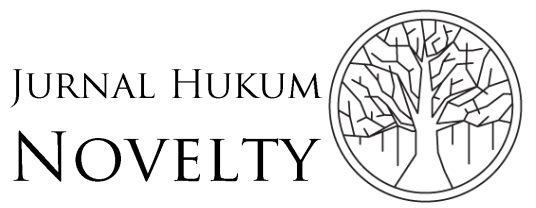

Volume 10, Issue 02, 2019, pp. 164-178
P-ISSN: $1412-6834$

E-ISSN: 2550-0090

assessment by the judicial body (judicial review). However, general and abstract norms can only be controlled through legal mechanisms, namely, judicial review by the court (Aziz, 2010). The legal examination through legislative review and executive review mechanism is an internal assessment and not an external one, which means that the legislative institution and the executive institution are conducting the assessment themselves (Zakaria, 2019).

In Indonesia, executive review is the authority of the Ministry of Domestic Affairs, whose authority is given by Law No. 23 of 2014 concerning Regional Government. In this case the Minister of Domestic Affairs may cancel the regional head regulation, which is contrary to the higher laws, public interest, and morality.

Even though the enactment of Permenkumham Regulation No. 2 of 2019 has given the authority for the Ministry of Law and Human Rights to resolve the conflicting legal norms and regulations, the mechanism and its results are problematic. It because the legal object is the legal norm that governs the public interest. While in practice, dispute resolution through mediation is commonly known in private law cases, which implications related to those who are litigants.

Based on the background description above, this paper formulates two problems. First is how the existence of the Minister of Law and Human Rights Regulation No. 2 of 2019 concerning Disharmony Settlement of Regulations through mediation is. Second is how the mechanism process of resolving the conflicting legal norms through mediation and the legal implications of the resolution based on this regulation are.

\section{Methodology}

This study uses the method of normative juridical research, which is a study that aims to solve legal problems based on applicable legal provisions and legal theories related to the problem study. This study applies the statue approach, historical approach, and conceptual approach. This paper examines the authority of the Ministry of Law and Human Rights in resolving conflicting norms of laws and regulations through mediation channels based on the Minister of Law and Human Rights Regulation No. 2 of 2019 concerning the Settlement of Disharmony Regulations through Mediation. The legal materials used in this study are primary, secondary, and tertiary legal materials. Data analysis in this study uses qualitative approach, where related data will be collected to be studied and examined to understand the problem or object of the research so that it can draw a conclusion to be presented descriptively. Thus, the research results will make the reader is easier to understand the substance of the research conducted. 
P-ISSN: $1412-6834$

E-ISSN: 2550-0090

\section{Results and Discussion}

\section{The authority of Kemenkumham in Permenkumham No. 2 of 2019}

The doctrine of the legal hierarchy is a result of the influence of thought developed by Hans Kelsen (Hoesein, 2006). Hans Kelsen, through his theory of the level of legal norms (stufentheorie), said that the legal norms are tiered and multi-layered in a hierarchy (arrangement). This means an applicable norms in the lower hierarchical position derived from the higher norms, as well as the higher norms in question are formed based on the more higher norms, and so on up to the basic norms that cannot be explored any further because they are considered as the basic norms as referred to by Hans Kelsen as grundnorm (Frew, 2013; Kelsen, 2006). This theory was later developed by Hans Nawiasky through his work entitled Allgemeine Rechtslehre als System der rechtlichen Grundbegriffe (Astomo, 2018). The theory developed by Hans Nawiasky is referred to by describing the following norms arrangement (Attamimi, 1990; Nawiasky, 1941; Sudrajat, Raharjo, Wasi Bintoro, \& Saefudin, 2018):

1. Staatsfundamentalnorm (fundamental norms of the country);

2. Staatsgrundgesetz (basic rules of the State);

3. Formell gesetz (formal law); and

4. Verordnung en autonome satzung (implementing regulations and autonomous regulations).

In terms of implementing regulations (Verordnung) and autonomous regulations (Autonome Satzung), the regulations in question are hierarchically beneath the laws, and their function is to regulate further the provisions in the laws (Antariksa, 2017). Furthermore, the implementing regulations were sourced from the delegation authorization while the autonomous regulations from the attribution authorization (Wicaksono, 2013). A. Hamid S. Attamimi then contextualizes Hans Nawiasky's norm arrangement into the legal hierarchy in Indonesia, in which Verordnung en autonome satzung was categorized hierarchically from government regulations to regent or mayor regulations (Attamimi, 1990).

From above explanation, it can be seen by using Article 7 section (1) and Article (8) section (1) of Law No. 12 of 2011 as a reference, that the ministry regulation is Verordnung en autonome satzung which its establishment is from delegation and/or attribution authorization. Law is included in dynamic norms (nomodinamyc) because the law is always established and wiped out by institutions or authorities that have the said authority. In this context, it does not examine the content of the norms yet its enactment. Law is valid when enacted by authorized institutions or authorities and based on the above norms. Therefore, the law shall be hierarchical or tiered (Kelsen, 2006; Yuliani, 2017).

In a modern state of law, one of the legislation functions is as an effective method and instrument for directing society towards the ideals expectation (Hsb, 2017). Article 1 section (3) of the 1945 Constitution of the Republic of Indonesia emphasizes that Indonesia is the state based on the rule of law. The implication of this provision 


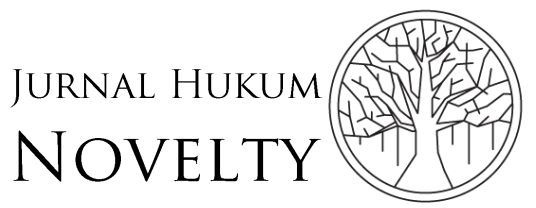

Volume 10, Issue 02, 2019, pp. 164-178
P-ISSN: $1412-6834$

E-ISSN: 2550-0090

requires that every action taken by the government in carrying out government activities must be based on law, or commonly known as the principle of legality. Thus, the implementation of government activities shall be based on legislation as the basis or the source of government authority in running the wheels of government (Mustamu, 2011). Theoretically, authority derived from legislation has three ways of authorization: attribution, delegation, and mandate (Hermawan, 2017; Kadarsih, 2010).

Law No. 30 of 2014 concerning Government Administration explained that attribution is authorization to a Government Body and/or Officer based on the 1945 Constitution or the law. Delegation is authorization from the higher Body and/or Officer to the lower one with transfer of responsibility and accountability to the delegate. Mandate is authorization from the higher Government Body and/or Officer to the lower one with responsibility and the responsibility is still on the superior.

Table 1. The Differences between Attribution, Delegation, and Mandate According to Sadjiono (Sadjijono, 2008)

\begin{tabular}{|c|c|c|c|}
\hline $\begin{array}{l}\text { Differentiation } \\
\text { Variable }\end{array}$ & Attribution & Delegation & Mandate \\
\hline $\begin{array}{l}\text { Ways of } \\
\text { Authorization }\end{array}$ & Legislation & Assignment & Assignment \\
\hline The binding force & $\begin{array}{l}\text { Remain attached } \\
\text { before any } \\
\text { amendment of } \\
\text { legislation }\end{array}$ & $\begin{array}{l}\text { Withdraw-able } \\
\text { if there is } \\
\text { conflict of } \\
\text { irregularities }\end{array}$ & $\begin{array}{l}\text { Withdraw-able } \\
\text { or usable at any } \\
\text { time by the } \\
\text { superior } \\
\text { institution }\end{array}$ \\
\hline $\begin{array}{l}\text { Responsibility and } \\
\text { Accountability }\end{array}$ & $\begin{array}{l}\text { Attributes are } \\
\text { absolutely } \\
\text { responsible for } \\
\text { the consequences } \\
\text { arising from the } \\
\text { authority }\end{array}$ & $\begin{array}{l}\text { The superior } \\
\text { assigns the } \\
\text { responsibility } \\
\text { and } \\
\text { accountability } \\
\text { to the delegate }\end{array}$ & $\begin{array}{l}\text { Belong to the } \\
\text { superior } \\
\text { institution }\end{array}$ \\
\hline $\begin{array}{l}\text { Relationship of } \\
\text { authority }\end{array}$ & $\begin{array}{l}\text { Legal relation to } \\
\text { establish the laws } \\
\text { with the } \\
\text { government } \\
\text { organs }\end{array}$ & $\begin{array}{l}\text { Based on the } \\
\text { attribution } \\
\text { authority which } \\
\text { is delegated to } \\
\text { the delegate }\end{array}$ & $\begin{array}{l}\text { Internal relation } \\
\text { between the } \\
\text { subordinates } \\
\text { and the } \\
\text { superior }\end{array}$ \\
\hline
\end{tabular}

Based on the explanation above, the attribution authorization means the initial authority given by a statutory regulation, by which the recipient of authority (attribute) can create new authority or expand the existing authority. Whereas, in the case of delegation, it does not bring up new authority because it is only delegating the existed authority from officials who attributively authorized to other officials. The legal responsibility of attribution and delegation authorization fell on to the attribute and the delegate, both internal and external. Unlikely, mandates only act for and on behalf of the superior. 
In regards with the authority of establishment of legislation, there are 'only' attribution and delegation scheme of authorization (Sjarif, 2015). Attribution of authority in the formation of laws and regulations (attributie van wetgevingsbevoegdheid) is the authorization to form laws and regulations granted by the Constitution (Grondwet) or laws (Wet) to an institution/government. The delegation of authority in the formation of laws and regulations (delegatie van wetgevingsbevoegdheid) is the authorization to form laws and regulations which are carried out by the superior laws and regulations to the inferior one (Sjarif, 2017; Suherman, 2017). The benefit of the consistent delegation of legislation is to avoid overlapping legislation, both vertically and horizontally (Sukardi \& Widiati, 2012).

There are differences in the application of authority between the context of running the government and the establishment of legislation. The differences between both are as follow:

Table 2. The differences between authority in running the government in general and authority to form laws and regulations (Sjarif, 2015)

\begin{tabular}{|c|c|c|}
\hline \multicolumn{3}{|c|}{ Differences of the nature and the concept of authority } \\
\hline $\begin{array}{l}\text { Run the government in } \\
\text { general }\end{array}$ & $\begin{array}{l}\text { Establishment of the Laws } \\
\text { and Regulations }\end{array}$ & Explanation \\
\hline $\begin{array}{l}\text { There are three types, } \\
\text { namely: } \\
\text { 1. Attribution; } \\
\text { 2. Delegation; } \\
\text { 3. Mandate }\end{array}$ & $\begin{array}{l}\text { There are } 2 \text { types, } \\
\text { namely: } \\
\text { 1. Attribution; } \\
\text { 2. Mandate }\end{array}$ & $\begin{array}{l}\text { The authority to establish } \\
\text { the laws and regulation is } \\
\text { one of the authorities of } \\
\text { the officials (including the } \\
\text { government officials), } \\
\text { thus it takes the similar } \\
\text { theory as in the theory of } \\
\text { state administrative law } \\
\text { regarding the source of } \\
\text { government authority }\end{array}$ \\
\hline $\begin{array}{l}\text { Authority is exercised in } \\
\text { the affairs of institutions } \\
\text { which carry out } \\
\text { executive (government) } \\
\text { authority only. }\end{array}$ & $\begin{array}{l}\text { Authority is exercised not } \\
\text { only by one institution } \\
\text { that holds executive } \\
\text { power, but can also be } \\
\text { exercised by the } \\
\text { legislative body. }\end{array}$ & $\begin{array}{l}\text { In the establishment of } \\
\text { laws and regulations, it is } \\
\text { not always the delegation } \\
\text { of authority between the } \\
\text { executive institutions, but } \\
\text { also for legislative } \\
\text { authority products, the } \\
\text { authority is given to the } \\
\text { executive institutions. The } \\
\text { uniqueness of delegation } \\
\text { in regards to the } \\
\text { legislation establishment } \\
\text { is that the delegation } \\
\text { could be from different } \\
\text { institutions. Thus, there }\end{array}$ \\
\hline
\end{tabular}




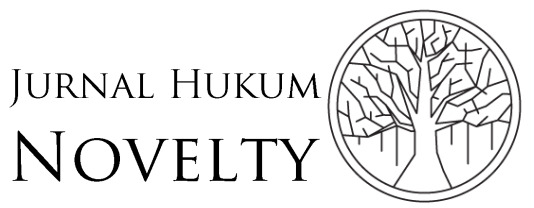

Volume 10, Issue 02, 2019, pp. 164-178
P-ISSN: $1412-6834$

E-ISSN: 2550-0090

\begin{tabular}{|c|c|c|}
\hline & & $\begin{array}{l}\text { shall be more attention to } \\
\text { its limitations. }\end{array}$ \\
\hline $\begin{array}{l}\text { The relationship in this } \\
\text { authority is derived } \\
\text { from the relationship } \\
\text { between official to } \\
\text { official }\end{array}$ & $\begin{array}{l}\text { The relationship in this } \\
\text { authority is originally } \\
\text { derived from the } \\
\text { relationship between the } \\
\text { regulations to regulation. } \\
\text { Only after the regulation } \\
\text { give or delegate the } \\
\text { authority, there will be } \\
\text { officials who implement } \\
\text { it. }\end{array}$ & \\
\hline $\begin{array}{l}\text { Generally, authority of } \\
\text { government relates to } \\
\text { the instruction of the } \\
\text { superior to the } \\
\text { subordinates. }\end{array}$ & $\begin{array}{l}\text { The legislation authority } \\
\text { is not always the case. }\end{array}$ & \\
\hline
\end{tabular}

Neither the 1945 Constitution nor the law, precisely Law No. 39 of 2008, provide attribution authority to Kemenkumham to settle the conflict of norms in the legislation through mediation. Moreover, there is also no delegation authorization as it only transfer of authority belong to superior government body and/or official to the inferior one and does not create new authority. Furthermore, the duties and functions of Kemenkumham are governed in the Presidential Regulation No. 44 of 2015, and the duties and functions of Directorate general are subject to the Permenkumham No. 29 of 2015. Neither both regulation bestow the regulation of the mediation as the resolution to the conflict of norms in the legislation.

Therefore, it is bizarre that the preamble of the Permenkumham No. 29 of 2015 mentions "in accordance to the duties and functions of the Directorate General of Legislation to resolve the legislation disputes out of court." Furthermore, the next point mentions that in order to increase the efforts to resolve the disharmony of laws and regulations through mediation, it is necessary to substitute Permenkumham No. 32 of 2017 by stipulating Permenkumham concerning the Settlement of Disharmony of Laws and Regulations through Mediation.

The fundamental problem of the preamble is about the legal basis used to say that the Directorate General of Legislative Regulations has the duty and function of resolving disputes over laws and regulations outside the court. As traced in Permenkumham No. 29 of 2015 concerning the Organization and Work Procedure of the Ministry of Law and Human Rights, there is no regulation showing that one of the duties and functions of the Directorate General of Legislation is to resolve disputes in the laws and regulations outside the court or through mediation channels. The establishment of Permenkumham No. 2 of 2019, which at the same time also revoked Permenkumham No. 32 of 2017, does not necessarily answer the substantial problems in 
P-ISSN: $1412-6834$

E-ISSN: 2550-0090

Permenkumham No. 32 of 2017 regarding the basis of the formation and content of the material it regulates, including the mechanism and legal consequences.

Furthermore, in the material content, especially in Article 1 number (3), it is said that mediation is carried out by the Directorate General of Legislation, Ministry of Law and Human Rights. Then, Article 2 states that the types of laws and regulations examined through mediation are:

1. Ministerial regulation;

2. Regulation of Non-Ministerial Government Institutions;

3. Regulations from Non-Structural Institutions; and

4. Regional laws and regulations

Structurally speaking, the position of the Directorate General of Legislation is inferior and bear the responsibility to the Minister (Perpres No. 44, 2015). In this case, how the Directorate General of the Legislation could have the authority to form the Assembly of Examiners to examine the ministerial level of regulation established by the minister (Permenkumham No. 2, 2019). Reflecting from the judicial review conducted by Constitutional Court and Supreme Court, the legislation that becomes the object of the review is the rule of law established by state institutions that are hierarchically equivalent or -in the context of the Supreme Court- the inferior one.

In addition to those above, the formation of Permenkumham No. 2 of 2019 also has a problem. As the ministerial level of regulation shall be based on delegation authorization, thus the formation of the regulation shall be under the command from the superior regulations. In regards to the delegation authority of the formulation of legislation, it could be exercised explicitly and implicitly (Sjarif, 2015).

The explicit delegation authority is the delegation that occurs when the law explicitly and in written commands to regulate further in government regulation. The implicit delegation authority means the delegation can be executed without any written and explicit command regarding the required material content in the government regulation. The later occurs when further arrangements are needed to enact a law (Sjarif, 2015).

The president's authority to explicitly and implicitly establish government regulation creates two types of government regulations, namely material and formal government regulation. Government regulation is material in nature when the regulation is created by explicit delegation authority. It is material because the regulation contains the scope of material required by an act. On the other hand, government regulation is formal when it is created by implicit delegation authority. The formality nature occurs due to its regulation material content can be determined by the formal authority of the president as the supreme ruler who authorizes to create the regulation to enforce the law as specified in Article 5 section (2) of the 1945 Indonesian Constitution and its explanations. With such formal authority, the president is authorized to elaborate further regulation to enforce an act (Sjarif, 2015). 


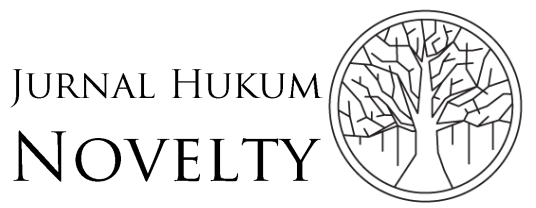

Volume 10, Issue 02, 2019, pp. 164-178
P-ISSN: $1412-6834$

E-ISSN: 2550-0090

Based on the above explanation, it is substantially afforded to say that the delegation of authority of the legislation establishment is both explicitly and implicitly transferable, which further creates the regulation as the receiver of delegation is material and formal. In the context of Permenkumham No. 2 of 2019, there was no written or implied delegation of authority. Explicitly, Permenkumham No. 2 of 2019 is not putting the base on the explicit and written instructions from the higher laws; thus, it is not material as it does not contain the higher legislation material scope. Implicitly, Permenkumham No. 2 of 2019 is unclear in which legislation it elaborates further. Formally speaking, there is no higher statutory regulation that gives Menkumham authority to be able to further regulate the provisions of the higher statutory regulations through the minister of law and human rights regulations. Therefore, it can be said that in its formation process, Permenkumham is not based on the presence of a delegation. In terms of its implementation, the resolution of disharmony regulations is not part of the duties and functions of the Directorate General of Legislation, as stipulated in Permenkumham No. 29 of 2015.

Mediation Mechanism based on Permenkumham No. 2 of 2019 and Its Legal Consequences

\section{Mediation Mechanism of Conflict of Norms in the Legislation Based on Permenkumham No. 2 of 2019}

Theoretically, there are several mechanisms for examining the laws and regulations, namely testing mechanisms through judicial institutions (judicial review), legislative bodies (legislative review), and executive institutions (executive review) (Huda, 2008). Legislative review mechanism is usually carried out by the countries adhering to the doctrine of Supremacy of the Parliament, where the parliament has the highest position in the state institutional structure so that considered as the most authorized in interpreting the Constitution. Therefore, the constitutional review of particular laws becomes the absolute authority of this supreme institution (Armia, 2017).

Subject to Permenkumham No. 2 of 2019, the mechanism for disharmony settlement of legislation is carried out through mediation. The mediation is executed as follows:

1. Hearing to the statements from the Petitioner and the Related Parties;

2. Hearing to the legal opinion of the Experts;

3. Do clarification to the Parties;

4. Conclude and read out the result of the mediation. (Permenkumham No. 2, 2019).

Before the enactment of Permenkumham No. 2 of 2019, the mediation as the nonlitigation case settlement mechanism is regulated in several laws and regulations. The laws and regulations governing the mediation mechanism as the dispute or case settlement are among others: 
Table 3. Laws and Regulations governing mediation

\begin{tabular}{|c|c|c|}
\hline $\begin{array}{c}\text { Laws and } \\
\text { Regulations }\end{array}$ & Article & Scope \\
\hline $\begin{array}{l}\text { Law Number } 48 \text { of } \\
2009 \text { concerning } \\
\text { Judicial Power }\end{array}$ & $\begin{array}{l}\text { Article } 58 \\
\text { Efforts to resolve civil disputes can be } \\
\text { done outside the state court through } \\
\text { arbitration or alternative dispute } \\
\text { resolution } \\
\text { Article } 60 \\
\text { Alternative dispute resolution is an } \\
\text { institution dispute resolution or } \\
\text { dissent through procedures agreed } \\
\text { by the parties, namely settlement } \\
\text { outside the court by means of } \\
\text { consultation, negotiation, mediation, } \\
\text { conciliation, or expert judgment. }\end{array}$ & Private \\
\hline $\begin{array}{l}\text { Law Number } 30 \text { of } \\
1999 \text { concerning } \\
\text { Arbitration and } \\
\text { Alternative } \\
\text { Disputes } \\
\text { Resolution. }\end{array}$ & $\begin{array}{l}\text { Article } 6 \text { section } 5 \\
\text { After the appointment of the } \\
\text { mediator by the arbitration } \\
\text { institution or an alternative dispute } \\
\text { resolution agency, within } 7 \text { (seven) } \\
\text { days the mediation effort must be } \\
\text { started. }\end{array}$ & Private \\
\hline $\begin{array}{l}\text { Supreme Court } \\
\text { Regulation } \\
\text { Number } 1 \text { of } 2016 \\
\text { concerning } \\
\text { Mediation } \\
\text { Procedures in the } \\
\text { Court }\end{array}$ & $\begin{array}{l}\text { Article } 4 \text { section (1) } \\
\text { All civil disputes submitted to the } \\
\text { Court, including cases of resistance } \\
\text { (verzet) on verstek decisions and } \\
\text { litigants' resistance (partij verzet) or } \\
\text { third parties (derden verzet) against } \\
\text { the implementation of decisions that } \\
\text { have permanent legal force, must first } \\
\text { be sought settlement through } \\
\text { Mediation, unless determined others } \\
\text { based on this Supreme Court } \\
\text { Regulation. }\end{array}$ & Private \\
\hline
\end{tabular}

The mediation mechanism is also known in Law No. 37 of 2008 concerning the Ombudsman of the Republic of Indonesia. As stated in Article 8 section (1) letter e, in carrying out its functions and duties as regulated in Articles 6 and 7, the Ombudsman is authorized to complete reports through mediation and conciliation at the request of the parties. The report in question is a complaint or delivery of facts that are resolved or acted upon by the Ombudsman which is submitted in writing or verbally by every person who has been a victim of maladministration. Article 1 number (3) of Law No. 37 of 2008 explains: 


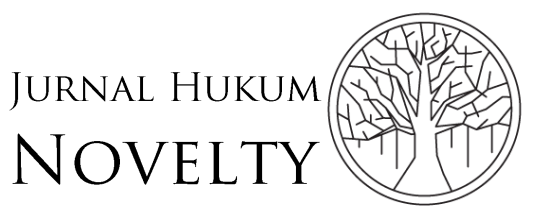

Volume 10, Issue 02, 2019, pp. 164-178
P-ISSN: $1412-6834$

E-ISSN: 2550-0090

"Maladministration is behavior or act against the law, exceeding authority, using authority for other purposes than those intended, including negligence or neglect of legal obligations in the administration of public services carried out by state and government administrators that cause material and/or immaterial losses for community and individuals."

The object of mediation and conciliation carried out by the Ombudsman is an act of maladministration carried out by state and government administrators, which causes material and/or immaterial losses to the community and individuals. In this case there are concrete events that directly involve the reported party so that in the mediation process the reported party acts for and on his own behalf. Thus the mediation mechanism can be carried out effectively because it involves the parties directly. From this explanation it can be seen that the object of mediation and conciliation carried out by the Ombudsman is an act of maladministration carried out by state and government administrators which causes material and/or immaterial losses to the community and individuals, which means that there are concrete events that directly involve the party reported. In the mediation process, the reported party acts for and on its own behalf, so that the mediation mechanism that is carried out can be effective because it involves the actors directly and the results of the mediation can also be carried out directly.

Seeing the practice so far, the application of dispute resolution through mediation outside the court as described above is known in disputes or private cases, as stated in the Black's Law Dictionary that mediation is "A method of nonbinding dispute resolution involving neutral third party who tries to help the disputing parties reach a mutually agreeable solution; conciliation" (Garner, 2010). Thus, in the mediation process, the parties act for and on their own behalf so that the resulting agreements have individual implications which can then be directly binding and carried out by the parties.

Unlike the case with the regulation in Permenkumham No. 2 of 2019 which applies mediation mechanisms in resolving conflicting norms of laws and regulations, in which the laws and regulations here are generally binding legal norms that are not private or aimed at specific people/groups. As Maria Farida said, general legal norms are norms intended for all people or every citizen and not for certain people or communities (Indrati, 2007). Thus the enactment of a legislation regulation will always relate to the public in general.

Permenkumham No. 2 of 2019 mentions that the output of the settlement of the disharmony of legislation through mediation is the agreement of the parties or recommendations. This output is then manifested in the minutes of agreement signed on the stamp by the parties. The minutes of the agreement shall be binding and applies to the parties. While recommendations are made if there is no agreement between the parties. 
The confusion that arises from this mechanism is about how the legitimacy of the parties negotiating in the process of finding the agreement is, especially in the context of regional regulations, because the object being negotiated is the statutory regulation governing the public or involving the public interest. Can their role in this matter represent the public interest or is based on their personal interests? Because if through a judicial institution, the final result is not an agreement between the parties but some judges decide fairly based on the Almighty God and are independent.

As in regional regulations, according to the Law No. 12 of 2011, it is established by the DPRD (Regional House of Representatives) with the joint agreement of the governor/regent/ mayor. These laws and regulations are formed by two institutions together, namely the head of the region and the DPRD institution, which then gives birth to legislation at the provincial/district/city level (regional regulations).

When the object of is this regional regulation, it raises a question as to how can this mediation mechanism be used to harmonize regulations regional regulation? Because it will be difficult to decide which party can represent all members of the DPRD to determine the agreement that will be included in the minutes of the agreement. Furthermore, even if the result is a recommendation to the president, this still does not have a definite impact legally because the president cannot intervene in regional regulations, which are the domain of the regional head and DPRD.

\section{Legal Implications of Mediation Results Based on Permenkumham No. 2 of 2019}

Article 14 of Permenkumham No. 2 of 2019 said that the mediation results of the disharmony resolution of the legislation are in the form of an agreement between the parties or recommendations. It is recommendations when there is no agreement between the parties in the mediation process. In contrast, if there is an agreement among parties, it shall be stated in the minutes of the agreement, which is binding and applies to the parties. Furthermore, the parties must implement the agreement no later than 30 calendar days or according to the agreement of the parties, and if it is not carried out, the Examining Panel gives consideration to Menkumham to submit recommendations to the president.

Judging from the regulation of the results (output) of the mediation, it has no legal implication. Likely in the agreement of the parties, which is then followed by the minutes of the agreement, even if the parties agree to revoke, change, or form a new statutory regulation, it still does not change the binding power of the said laws and regulations. In other words, even though there is an official report of the agreement signed by the parties, it also does not change the binding force or legal force of the laws and regulations until the laws and regulations are revoked or changed by the competent authority.

Substantially, the minutes of the agreement signed by the parties are only morally binding but not legally, because in addition to not changing the status or enactment of the said laws and regulations, the minutes of the agreement also cannot be used as 


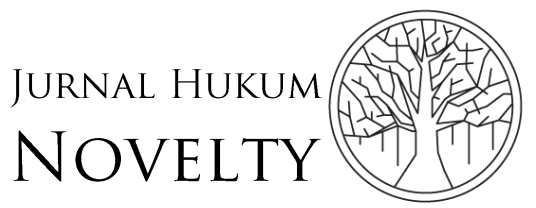

Volume 10, Issue 02, 2019, pp. 164-178
P-ISSN: $1412-6834$

E-ISSN: 2550-0090

a basis for urging the parties to follow the contents of the agreement or take other legal remedies if the agreement is not implemented. Then this mechanism will also be strange if the object of mediation is a regional regulation (Perda) because, in the case of changes, revocation, or the formation of new ones, it must involve the head of the regional and other DPRD members. In a way that the agreement is made by several people or parties in the mediation, it is not necessarily agreed upon by other DPRD members.

If the parties do not implement the agreement, Permenkumham No. 2 of 2019 governs that it would be followed up by giving recommendations to the president. The effort to provide recommendations to the president is not a practical step because it cannot guarantee legal certainty. The recommendation in nature is a suggestion that advocates or justifies or reinforces a proposal or suggestion to be earnestly carried out (Soesilo dan Jimmy, 2009: 531). Thus, it is afforded to say that recommendations are merely a suggestion that can be done or undone because there are no legal obligations or consequences. Thus, there is no legal certainty that can be guaranteed by the settlement of the disharmony of laws and regulations through mediation based on Permenkumham No. 2 of 2019.

\section{Conclusion}

Based on the research and discussion described above, we could conclude that the mediation as the resolution to the conflict of laws should have been not the authority of the Ministry of Law and Human Rights or Directorate General of Laws and Regulations, as no legislation gives the authority to Kemenkumham, neither attribution authorization nor delegation authorization. The authority of mediation comes from the internal regulation established by the Minister of Law and Human Rights, as the so-called Permenkumham No. 2 of 2019. The establishment of Permenkumham No. 2 of 2019 itself is theoretically a mistake. The ministerial regulation shall be under the delegation authorization. Therefore, the establishment shall subject to the commands of the superior legislation. This delegation might be explicit or implicit. However, this delegation authorization is absent as a legal basis in the establishment of Permenkumham No. 2 of 2019.

Mediation as the settlement mechanism of the disharmony of legislation as stipulated in Permenkumham No. 2 of 2019 is not appropriate because the concept of mediation as the dispute or case settlement is commonly known in private law where the parties act for and on their own behalf and the implications are individual. While the laws and regulations are legal products that regulate the public interest, it is bizarre if the resolution of the conflict uses a mediation mechanism as the object to be agreed in mediation related to interests of the people, it will not affect only to those who agree in the mediation. Furthermore, if the object of mediation is a regional regulation, the mechanism for revocation, amendment, and formation cannot be determined by individuals or certain parties but requires the support of the regional head and other DPRD members. Therefore, the results of the harmonization of the legislation based 
on Permenkumham No. 2 of 2019 does not have legal certainty, which then impacts the effectiveness of its implementation.

\section{References}

Aditya, Z. F., \& Winata, M. R. (2018). Rekonstruksi hierarki peraturan perundangundangan di Indonesia. Negara Hukum, 9(1), 79-100. https://doi.org/10.22212/jnh.v9i1.976

Antariksa, B. (2017). Penerapan hierarki peraturan perundang- undangan dalam ketatanegaran indonesia. DeliberatifJurnal Ilmiah Hukum, 1(1), 24-41. Retrieved from http://ojs.uscnd.ac.id/index.php/deliberatif/article/view/8

Armia, M. S. (2017). Mahkamah konstitusi dan pengujian undang-undang: Pembelajaran bagi Indonesia. Negara Hukum, 8(1), 107-130. https://doi.org/10.22212/jnh.v8i1.940

Astomo, P. (2018). Supervision of local government to village regulation in regional autonomy are reviewed theory. Indonesia Prime, 2(1), 45-49. https://doi.org/10.29209/id.v2i1.18

Attamimi, A. H. S. (1990). Peran keputusan presiden Republik Indonesia dalam penyelenggaraan pemerintahan negara; Suatu studi analisis mengenai keputusan Presiden yang berfungsi pengaturan dalam kurun waktu Pelita I-Pelita IV. Universitas Indonesia. Unpublished Thesis.

Aziz, M. (2010). Pengujian peraturan perundang-undangan dalam sistem peraturan perundang-undangan Indonesia. Jurnal Konstitusi, 7(5), 113-150. Retrieved from http://ejournal.mahkamahkonstitusi.go.id/index.php/jk/article/view/248

Frew, K. (2013). Hans Kelsen's theory and the key to his normativist dimension. The West Australian Jurist, 4(285), 285-293. Retrieved from https://www.murdoch.edu.au/School-of-Law/_document/Publications/TheWestern-Australian-Jurist/4WAJ285---Frew.pdf

Garner, B. A. (2010). Black's law dictionary (9th ed.). USA: Thomson Reuters.

Hermawan, B. (2017). Pelaksanaan wewenang Wakil Presiden dalam penyelenggaraan pemerintahan. Jurnal Hukum Volkgeist, 2(1), 24-34. https://doi.org/10.35326/volkgeist.v2i1.102

Hoesein, Z. A. (2006). Pengujian peraturan perundang-undangan menurut konstitusi Indonesia studi tentang perkembangan pengaturan dan pelaksanaanya oleh Mahkamah Agung RI dalam kurun waktu 1970-2003. Universitas Indonesia. Unpublishes Thesis

Hsb, A. M. (2017). Kegentingan yang memaksa dalam pembentukan peraturan pemerintah pengganti undang-undang. Jurnal Legislasi Indonesia, 14(1), 109-122. Retrieved from http://ditjenpp.kemenkumham.go.id/jurnal/index.php/jli/article/view/27

Huda, N. (2008). Urgensi judicial review dalam tata hukum Indonesia. Jurnal Hukum IUS QUIA IUSTUM, 15(1), 101-120. https://doi.org/10.20885/iustum.vol15.iss1.art5

Indrati, M. F. (2007). Ilmu perundang-undangan, jenis, fungsi, dan materi muatan. Yogyakarta: Kanisius.

Kadarsih, S. (2010). Tugas dan wewenang Ombudsman Republik Indonesia dalam pelayanan publik menurut UU No. 37 Tahun 2008. Jurnal Dinamika Hukum, 10(2), 175-182. https://doi.org/10.20884/1.jdh.2010.10.2.150

Kelsen, H. (2006). General theory of law and state. London: Transaction Publisher. 


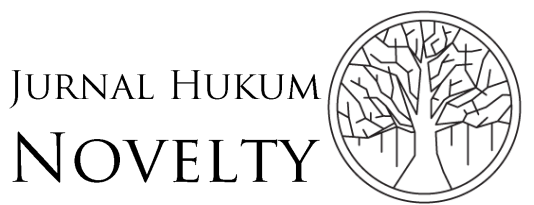

P-ISSN: $1412-6834$

Volume 10, Issue 02, 2019, pp. 164-178

Mustamu, J. (2011). Diskresi dan tanggungjawab administrasi pemerintahan. Jurnal Sasi, 17(2), 1-9. Retrieved from https://bit.ly/2p40SKy

Nawiasky, H. (1941). Allgemeine rechtslehre als system der rechtlichen grundbegriffe. Benziger.

Sadjijono. (2008). Memahami beberapa bab pokok hukum administrasi. Yogyakarta: Pressindo.

Sjarif, F. A. (2015). Pembentukan peraturan delegasi dari Undang-Undang pada kurun waktu 1999-2012. Universitas Indonesia. Unpublished Thesis

Sjarif, F. A. (2017). Gaya perumusan kalimat perintah pembentukan peraturan yang menjalankan delegasi dari undang-undang di Indonesia. Pakuan Law Review, 3(2), 31-50. Retrieved from https://journal.unpak.ac.id/index.php/palar/article/view/396

Sudrajat, T., Raharjo, A., Wasi Bintoro, R., \& Saefudin, Y. (2018). Harmonization of regulation in water territorial management becoming a fair economic benefit distribution towards regional autonomy. E3S Web of Conferences, 47, 1-6. https://doi.org/10.1051/e3sconf/20184706004

Suherman, P. K. (2017). Delegasi regulasi dan simplifikasi regulasi dalam pembentukan Peraturan Kepala Daerah. Jurnal Advokasi FH UNMAS, 7(1), 1-11. Retrieved from http://jurnal.unmas.ac.id/index.php/advokasi/article/view/702

Sukardi, \& Widiati, E. P. (2012). Pendelegasian pengaturan oleh Undang-Undang kepada Peraturan yang lebih rendah dan akibat hukumnya. Yuridika, 27(2), 141156. https://doi.org/10.20473/ydk.v27i2.293

Wicaksono, D. A. (2013). Implikasi re-eksistensi Tap Mpr dalam hierarki peraturan perundang- undangan terhadap jaminan atas kepastian hukum yang adil di Indonesia. Jurnal Konstitusi, 10(1), 143-178. Retrieved from http://consrev.mkri.id/index.php/jk/article/view/99

Yuliani, A. (2017). Daya ikat pengundangan peraturan perundang-undangan. Jurnal Legislasi Indonesia, 14(4), 429-438. Retrieved from http://ejurnal.peraturan.go.id/index.php/jli/article/view/121

Zakaria, E. H. P. (2019). Legislative review dewan perwakilan rakyat terhadap peraturan pemerintah pengganti undang-undang. Lex Administratum, 7(1), 62-70. Retrieved from https://ejournal.unsrat.ac.id/index.php/administratum/article/view/24546 